\title{
LABORATORY TESTING AND NUMERICAL ANALYSIS FOR EXPANSIVE SOIL TREATED BY POZZOLANIC MATERIALS
}

\author{
Zaki, A. H.* ${ }^{1}$, Al-Sedik, M. Abu Bakr ${ }^{2}$ and Gad, S. Abd El-Fattah ${ }^{3}$ \\ Civil Engineering Dept. Faculty of Engineering, Al-Azhar University, Cairo, Egypt \\ *Corresponding Author's E-mail: ahmed_zaki@azhar.edu.eg \\ Received: 06 June $2021 \quad$ Accepted: 29 June 2021
}

\begin{abstract}
This paper presents laboratory and numerical analysis on the behavior of expansive soils treated by Silica fume and Slag as a pozzolanic material. The laboratory tests divided into two series, the first using conventional oedometer and the other is laboratory physical model. Swelling potential of test expansive soil was determined the conventional oedometer. On the other hand, the untreated and treated expansive soils have been tested using the physical model for 45 days under light load condition. The numerical studies are based on simulating the tested soil by Plaxis-3D program. To model the behavior of expansive soil, elastoplastic models have been used. Hardening Soil Model (HSM) with volumetric strain value is chosen in this study. The results of laboratory tests indicated that; the soil contains high clay percentage, with active clay. Expansive soil treated with $5 \%$ of both Silica fume and Slag revealed better improvement with moderate swelling potential. The results of laboratory models found that; the swelling potential reduced by about $60 \%$ for soils treated by $5 \%$ of both Silica fume and Slag. Finally, the results of numerical analysis are found to be closed to the laboratory model. The swelling potential estimated from the oedometer test is about 4 times that observed from laboratory model.

Keywords: Expansive soil, Soil improvement, Finite element analysis, pozzolanic materials.

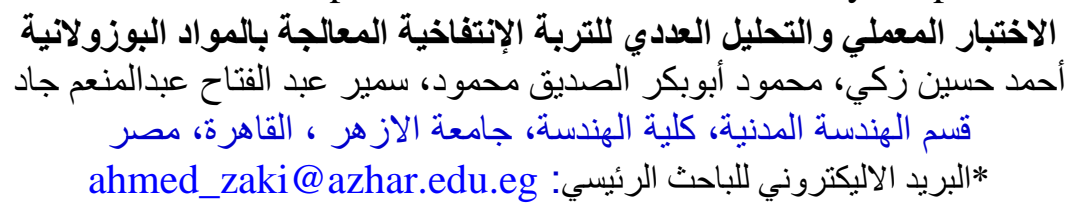

يقدم هذا البحث الاختبار المعملي والتحليل العددي لسلوك التربة الإنتفاخية المعالجة بالسليكا فيوم والخبث كمواد بوزلانية. تتقسم

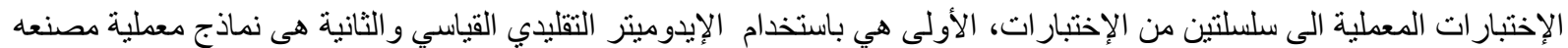

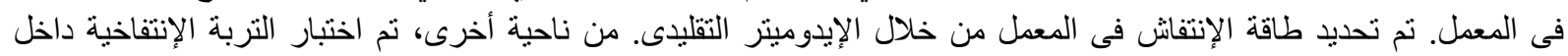

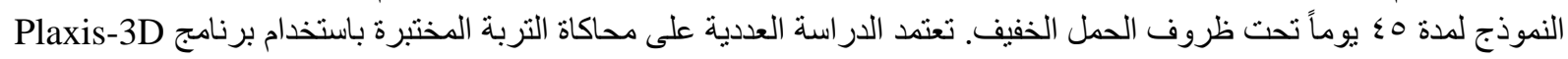

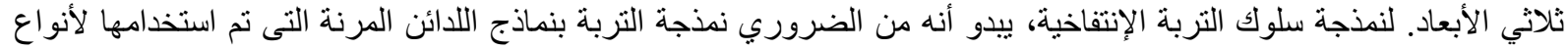

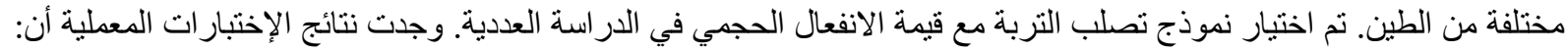

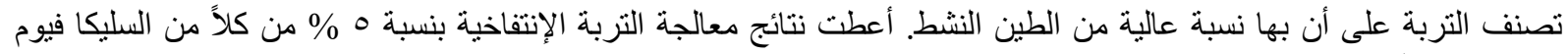

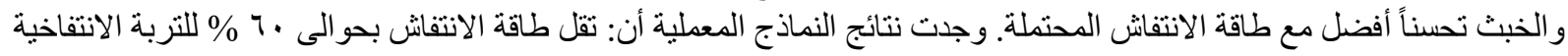
المعالجة بنسبة ه \% بكلاً من السليكا فيوم والخبث. أخيراً، أوضحت تحليل النماذج العددية أن: نتائج التحليل العددي قريبة جداً من
\end{abstract}




\section{نتائج النماذج المعطلية. تعادل طاقة الإنتفاش الحاصل عليها من تجربة الإيدوميتر ؛ مر ات القيمة الحاصل عليها من النموذج العملي.}

\section{Introduction}

In geotechnical practice light weight structures, such as pavements, single-story houses and railways founded on expansive clay are usually subject to distress due to swell-shrink cycles caused by the seasonal moisture variations. (ASTM D4546, 2014) provides three methods for evaluating the 'swell pressure' using the oedometer apparatus. One procedure includes measuring the increase in the height of specimen under either a nominal pressure or in-situ stress, followed by the loading down to the original height and further. The first phase measures the volume increase during wetting while the second phase measures the stress to counteract the swell potential. The stress required to bring the specimen to the original height is interpreted as the 'swell pressure'. The second procedure involves first loading specimen to the in-situ stress level and then inundating them with water while the load is added to keep the specimen at a constant volume. The final load applied is interpreted to be the 'swelling pressure'. Many researchers have used the ASTM procedures to obtain the swelling volume potential as well as the 'swelling pressure' (Sridharan \& Prakash, 2000) (Sridharan \& Gurtug, 2004) and (Thakur \& Singh, 2005). Current practices suggest solutions such as partial removal and replacement of such subgrade soil or stabilization. Due to the complex behavior of expansive soils in the presence of moisture, under loads, closed form analytical solutions for estimation of displacements are difficult. Therefore, numerical methods like Finite Difference Method (FDM) and FEM have been used to find the effect of moisture ingress through unsaturated expansive soils, heave and the corresponding volume changes. (Likitlersuang et al., 2018) studied strength and stiffness parameters by using the two material models available in Plaxis-3D namely, Mohr-Coulomb Model (MCM) and Hardening Soil Model (HSM). They observed that, the Bangkok clays are simulated better with HSM. Many researchers have used the MCM, while others used Soft Soil Model (SSM) and HSM for simulating expansive soils. (Al-Busoda et al., 2017) modeled the swelling of expansive soil layer by applying a swelling potential (positive volumetric strain) of $(6.5 \%)$ to the expansive soil cluster. This volumetric strain value was previously obtained from the free swell test of expansive soil used. (Al-Busoda \& Abbas, 2017) modeled the expansive soil by applying a swelling potential (positive volumetric strain) of $26.5 \%$. The main reason for swelling of expansive soils is the moisture ingress and swelling pressure goes on increasing. (Katti, 1979) tried a variety of solutions including removal and replacement of expansive clay subgrade by Cohesive Non-Swelling (CNS) material for controlling the volume changes occurring due to swell-shrink cycle. However, use of CNS has additional procurement cost and also gives rise to problems like disposal of expansive soils. (Sahoo \& Pradhan, 2010) observed that, the CNS is not effective after the first swell-shrink cycle. Therefore, pozzolanic material additives are, comparatively more effective compared to other additives. However, pozzolanic material to stabilize the complete depth of active zone up to 1-1.5 $\mathrm{m}$ of expansive soils is uneconomical. The aim of this study is to model the behavior of untreated and treated expansive soil using silica fume and slag as a pozzolanic by-product materials. The selected swelling soil taken from a subsoil formation at New Cairo and Nasr city distracts in Cairo, Egypt. A numerical model is prediction the behavior of expansive soils treated by Silica fume and Slag was modeled using Plaxis-3D, and compared with the results of the laboratory physical model. 


\section{Laboratory Tests}

The soil was dried in an oven at $105^{\circ} \mathrm{C}$ for 24 hours. The dry soil was pulverized, and the samples passing sieve 40 size was taken for laboratory preparation and testing. Silica fume and Slag were added to soil samples with ratio $1,3,5$, and $7 \%$ by dry weight of soil sample. The samples are tested by using the oedometer apparatus.

\subsection{Soil and Pozzolanic Materials}

Expansive soils; The soil samples used in this study for current experimental tests were collected from two locations in Cairo, Egypt. The soils were air-dried and broken into pieces in the laboratory. Soils were tested at the Soil Mechanics Laboratory at Faculty of Engineering, Al-Azhar University. The soils physical and engineering properties of the tested soil are illustrated in Table (1).

Table (1) Physical and Engineering Properties of Tested Soils

\begin{tabular}{|c|c|c|c|c|c|}
\hline Physical Properties & Soil-A & Soil-B & Engineering Properties & Soil-A & Soil-B \\
\hline Region & New Cairo & Nasr city & $\mathrm{OMC}(\%)$ & 21 & 18 \\
\hline Moisture Content (\%) & 12 & 6.5 & Max. Dry Density $\left(\mathrm{kN} / \mathrm{m}^{3}\right)$ & 15.4 & 15.1 \\
\hline Specific Gravity $\left(\mathrm{G}_{\mathrm{s}}\right)$ & 2.70 & 2.65 & Liquid Limit, (LL \%) & 90 & 79 \\
\hline$\%$ of Sand & 30 & 25 & Plastic Limit, (PL \%) & 32 & 33 \\
\hline Passing \% (Sieve No.200) & 70 & 75 & Plasticity Index (P.I \%) & 58 & 46 \\
\hline$\%$ of Silt & 10 & 27 & Shrinkage Limit (S.L \%) & 7 & 8 \\
\hline Clay content \% (C) & 60 & 48 & Uscs Classification & $\mathrm{CH}$ & $\mathrm{CH}$ \\
\hline Void Ratio $\left(\mathrm{e}_{\mathrm{o}}\right)$ & 0.477 & 0.514 & Activity $\left(\mathrm{A}_{\mathrm{c}}\right)=\frac{\text { P.I } \%}{\% \text { of Clay }}$ & 0.967 & 0.958 \\
\hline \multirow{2}{*}{\multicolumn{3}{|c|}{$\begin{array}{l}\text { * Swell \% according to (Carter and Bentley 1991) and } \\
\qquad \mathrm{k}=3.6 \times 10^{-5} .\end{array}$}} & Free Swell $\% *=60$ k P.I ${ }^{2.44}$ & 43 & 41 \\
\hline & & & Bulk Density $\left(\mathrm{kN} / \mathrm{m}^{3}\right)$ & 20 & 18.7 \\
\hline
\end{tabular}

The chemical analysis of Silica fume and Slag used as additives in this study are present in Table (2).

Table (2) Chemical analysis of Silica fume and Slag

\begin{tabular}{|c|c|c|c|c|c|c|c|c|c|}
\hline Chemical Content (\%) & $\mathrm{SiO}_{2}$ & $\mathbf{C a O}$ & $\mathrm{Al}_{2} \mathrm{O}_{3}$ & $\mathrm{SO}_{3}$ & $\mathrm{Fe}_{2} \mathrm{O}_{3}$ & $\mathbf{M g O}$ & $\mathrm{Na}_{2} \mathrm{O}$ & $\mathrm{TiO}_{2}$ & $\mathbf{P u r i t y}$ \\
\hline Silica Fume & 93.8 & 0.33 & 0.36 & 0.19 & 1.48 & 0.41 & 0.43 & 0.25 & $>95$ \\
\hline Slag & 33.28 & 37.1 & 13.12 & 2.21 & 3.15 & 7.74 & 1.20 & 0.40 & $>70$ \\
\hline
\end{tabular}

\subsection{Conventional Oedometer Results}

Traditional laboratory tests which deal with physical and engineering properties are established through the standard test according to The Egyptian geotechnical code of practice regulations. The tested soils can be classified as clay of high plasticity $(\mathrm{CH})$ as per the Unified Classification System (USCS). For soils A and B, the effect of adding Silica fume or Slag on swelling potential and swelling pressure are evaluated. Figures (1) and (2) show that, the swelling-Time curves comprise three distinct zones. The initial swelling is generated quickly due to hydration, second distinct is of high rate of increase in swelling potential, followed by a low rate in the secondary stage. 


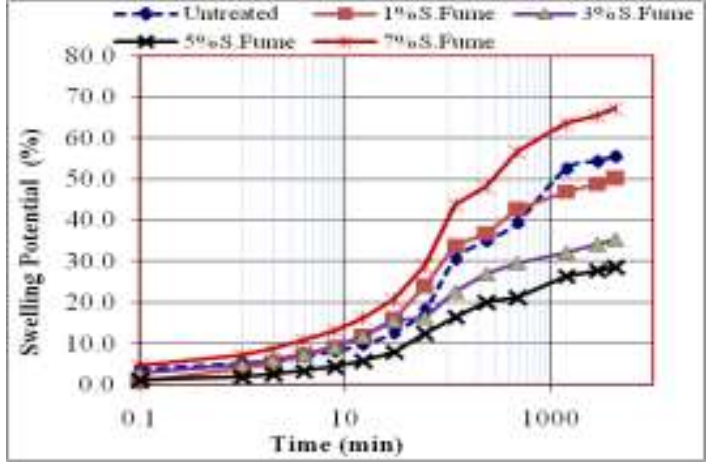

1-(a) Soil (A) with S.Fume

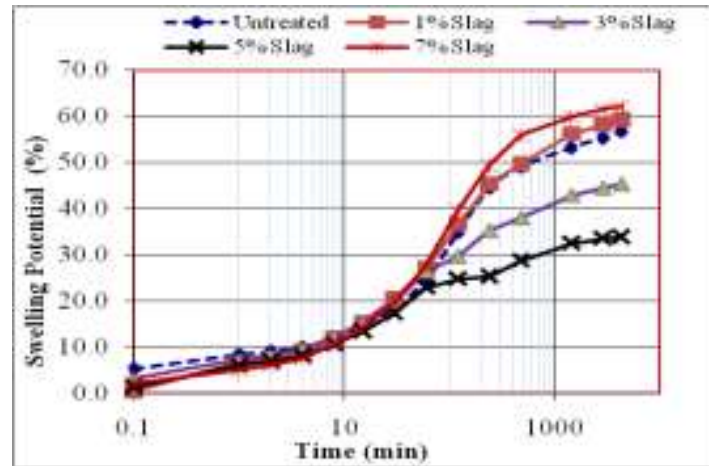

1-(b) Soil (A) with Slag

Figure (1) Swelling Potential - Time Curves for Soil (A) Treated by a. Silica fume and b. Slag.

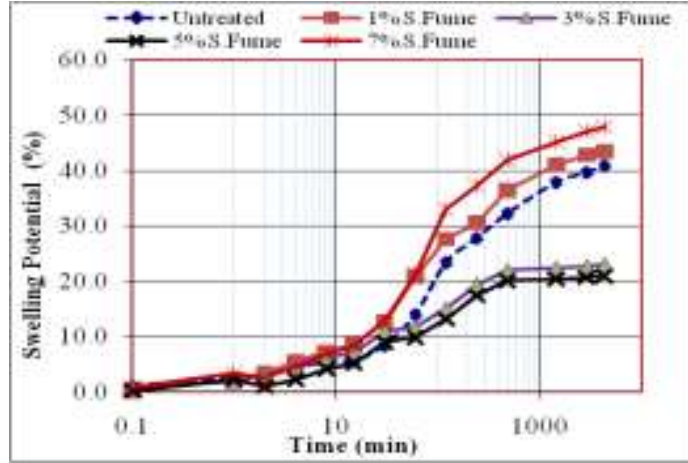

2-(a) Soil (B) with S.Fume

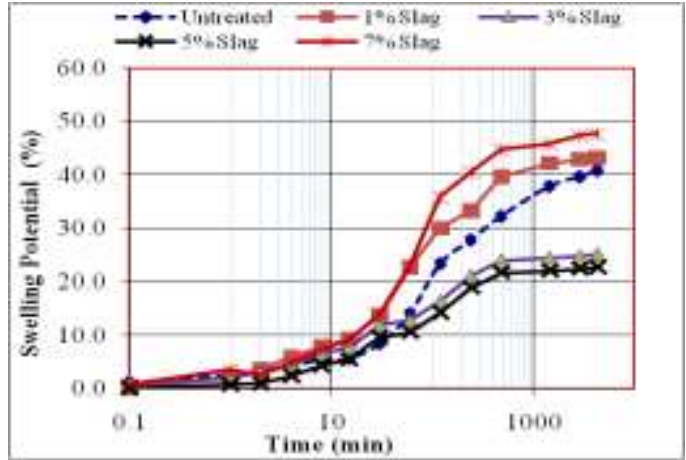

1-(b) Soil (B) with Slag

Figure (2) Swelling Potential - Time Curves for Soil B Treated by a. Silica fume and b. Slag.

\subsection{Laboratory Model test results}

Schematic drawing for the laboratory model test is shown in Figure (3), testing for both soils A and B, large amounts of grinded soils (A) \& (B) have been compacted in a securit glass box with inner dimension of $450 \mathrm{~mm}$ in side length of square base and the same length in height made as one piece. Each box was confined with metal angles. All tests were conducted at the laboratory of Civil Department, Faculty of Engineering at Al-Azhar University in Cairo, Egypt. Soil C tested by (Abdelrahman et al., 2021).

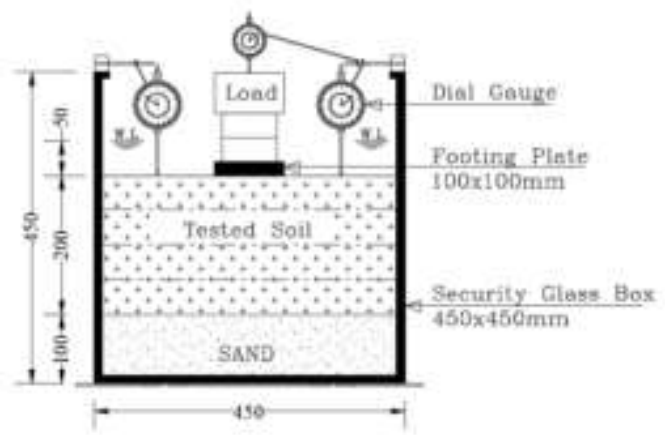

Figure (3) Setup of the model.

The soil was placed in an oven-dried at $105^{\circ} \mathrm{C}$ for 24 hours. The dry soil was pulverized to minus 40 sieve size. The soil was mixed with the additives at optimum percentage of $5 \%$ by weight of dry soil. For soil (A) $5 \mathrm{~kg}$ of sample was thoroughly mixed by hands with the OMC (21\%) until the entire amount became homogenous, and then stored for 24 hours in a plastic bag to ensure an equal distribution of water within the soil as suggested by (Agus et al., 2010) 
and (Vanapalli \& Taylan, 2012). The soil compacted in the box in four layers, and the depth of each layer was $50 \mathrm{~mm}$ to reach a full depth of $200 \mathrm{~mm}$ with bed sand $100 \mathrm{~mm}$. The securit glass sides of the wall were lubricated with Vaseline. To ensure the less friction between the compacted layers and the model sides, A hammer of $8.5 \mathrm{~kg}$ was used to compact the soil in the model to reach the MDD $\left(15.4 \mathrm{kN} / \mathrm{m}^{3}\right)$. The MDD of each layer was checked by using an oedometer ring which has constant dimensions of $63 \mathrm{~mm}$ in diameter and $20 \mathrm{~mm}$ in height, and the water content of each layer was also checked. After preparation of the soil within the box and placing the footing, one dial gauge of $0.01 \mathrm{~mm}$ resolution was placed at the center of footing and attached to the side of the metal frame box by magnetic holder. Two dial gauges of $0.01 \mathrm{~mm}$ resolution were then placed at the top of soil between footing and wall side, its attached to the side of the metal frame box by magnetic holder. The average values of measured settlement and swelling were recorded. The soil was then covered with thin plastic sponge to allow uniform distribution of water during the saturation stage.

\section{Numerical Model}

In this study the experimental models were simulated and verified using Finite Element Method (FEM) based on Software program Plaxis-3D as shown in Figure (4). The dimensions of the numerical models are the same dimensions of the experimental model as shown in Figure 1.

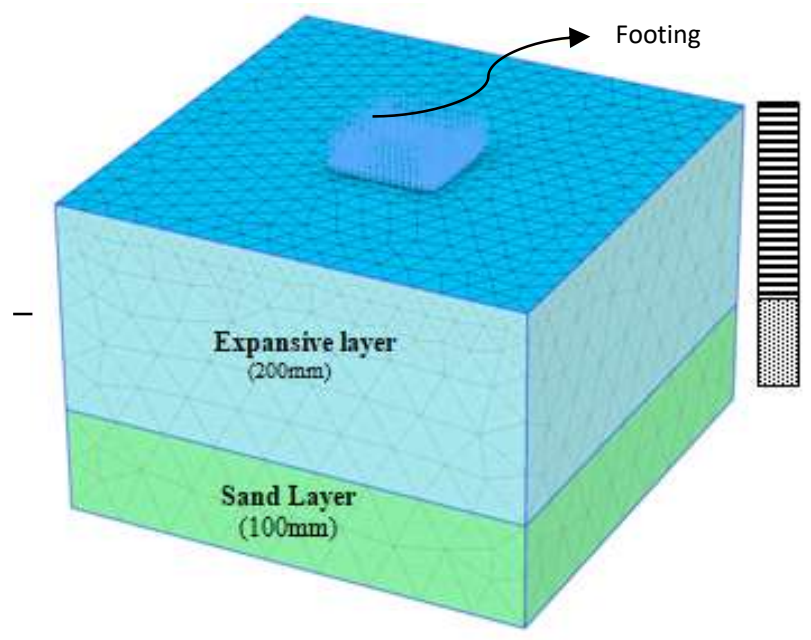

Figure (4) Numerical Model.

\subsection{Verification of Proposed Numerical Model}

The finite element model is composed of two types of soils, sandy layer, and clay as an expansive layer. HSM model with volumetric strain ratio and Van Genuchten Hydraulic Model are used in FEM based on Software Plaxis-3D. The rigid steel is used as a material for footing and assumed as linear elastic model. All materials with set of parameters are listed in Tables (3).

Three experimental models were previously studied by (Zaki et al., 2021) on each untreated and treated soils (A \& B) at optimum amount (5\%) of Silica fume or Slag, while the experimental model on untreated of Soil C was studied by (Abdelrahman et al., 2021), soil properties used in the FE analysis are listed in Table (4). 
Table (3) Steel Properties Considered in Finite Element Analysis

\begin{tabular}{|c|c|c|c|}
\hline Model Parameters & Model Parameters & Steel Footing & Unit \\
\hline Material type & Type & Elastic & -- \\
\hline Axial stiffness & EA & $1 \times 10^{12}$ & $\mathrm{kN} / \mathrm{m}^{2}$ \\
\hline Flexural rigidity & EI & $1 \times 10^{17}$ & $\mathrm{kN} / \mathrm{m}^{2}$ \\
\hline Unit Weight & $\gamma$ & 7850 & $\mathrm{kN} / \mathrm{m}^{3}$ \\
\hline Poisson`s Ratio & $v^{`}$ & 0.15 & -- \\
\hline Thickness & $t$ & 0.01 & $M$ \\
\hline Dimensions & $B$ & $0.1 \times 0.1$ & $M$ \\
\hline
\end{tabular}

HSM is used for simulating the expansive soil. In field conditions, the water table level is well below the expansive soil layers to cause any swelling strain. Therefore, to simulate the field conditions, mode of wetting due to water precipitation was applied. Positive volumetric strains $\left(+\varepsilon_{\mathrm{v}}\right)$ in positive $\mathrm{z}$-direction are applied through the selection explorer section of the software Plaxis-3D. Application of volume strain is necessary, as HSM does not account for swelling. The magnitude of $+\varepsilon_{\mathrm{v}}$ causing swelling is obtained from laboratory swelling test using consolidometer. $+\varepsilon_{\mathrm{v}}$ for clay clusters are as listed in Table (5).

Table (4) Soil Properties Considered in Finite Element Analysis

\begin{tabular}{|c|c|c|c|c|c|c|}
\hline Parameters & Name & Soil (A) & Soil (B) & Soil (C) & Sand & Unit \\
\hline Drainage Type & Model & \multicolumn{3}{|c|}{ Undrained(A) } & Drained & -- \\
\hline Unite Weight above Phreatic level & $\gamma_{\text {unsat. }}$ & 15.4 & 15.4 & 15.4 & 17 & $\mathrm{kN} / \mathrm{m}^{3}$ \\
\hline Unite Weight below Phreatic level & $\gamma_{\text {sat. }}$ & 18 & 18 & 18 & 20 & $\mathrm{kN} / \mathrm{m}^{3}$ \\
\hline Initial void ratio & $\mathrm{e}_{\text {init }}$ & 0.85 & 0.477 & 0.85 & 0.50 & -- \\
\hline Stiffness for triaxial test & $E_{50}^{r e f}$ & $2.5 \times 10^{4}$ & $2.5 \times 10^{4}$ & $2.0 \times 10^{4}$ & $4.3 \times 10^{4}$ & $\mathrm{kN} / \mathrm{m}^{2}$ \\
\hline Tangent oedometer stiffness & $E_{\text {oed }}^{\text {ref }}$ & $2.5 \times 10^{4}$ & $2.2 \times 10^{4}$ & $2.0 \times 10^{4}$ & $2.2 \times 10^{4}$ & $\mathrm{kN} / \mathrm{m}^{2}$ \\
\hline Unload/reload stiffness & $E_{u r}^{r e f}$ & $6 \times 10^{4}$ & $5.5 \times 10^{4}$ & $5.0 \times 10^{4}$ & $1.3 \times 10^{5}$ & $\mathrm{kN} / \mathrm{m}^{2}$ \\
\hline Cohesion & c'ref & 100 & 100 & 100 & 1 & $\mathrm{kN} / \mathrm{m}^{2}$ \\
\hline Friction angle & $\varphi$ & 25 & 25 & 25 & 34 & o \\
\hline Dilatancy angle & $\psi$ & 0 & 0 & 0 & 4 & o \\
\hline Poisson`s ratio & $v^{\top}$ & 0.2 & 0.2 & 0.2 & 0.2 & -- \\
\hline Clay $(<2 \mu \mathrm{m})$ & - & 70 & 75 & 70 & 4 & -- \\
\hline Silt $(2 \mu \mathrm{m}-50 \mu \mathrm{m})$ & - & 13 & 10 & 13 & 4 & -- \\
\hline Sand $(50 \mu \mathrm{m}-2 \mathrm{~mm})$ & & 17 & 15 & 17 & 92 & -- \\
\hline Interface strength & -- & \multicolumn{3}{|c|}{ Rigid } & Manual & -- \\
\hline Interface reduction factor & $R_{\text {inter }}$ & 1.0 & 1.0 & 1.0 & 0.5 & -- \\
\hline Reference stress for stiffness & $P^{r e f}$ & 100 & 100 & 100 & 100 & $\mathrm{kN} / \mathrm{m}^{2}$ \\
\hline$K_{0}^{n c}$ - value & $K_{0}^{n c}$ & 0.5774 & 0.5 & 0.5 & 0.4408 & -- \\
\hline
\end{tabular}

Table (5) Boundary conditions for volumetric strain values

\begin{tabular}{|c|c|c|c|}
\hline Testing & Soil & Clay layer + additive & Volumetric Strain Value $\left(+\varepsilon_{\mathbf{v}}\right) *$ \\
\hline 1 & \multirow{2}{*}{ A } & Untreated & $14 \%$ \\
\cline { 3 - 4 } 2 & & Soil A + 5\% Additive & $6.5 \%$ \\
\hline 3 & \multirow{2}{*}{ B } & Untreated & $10 \%$ \\
\cline { 3 - 4 } & & Soil B + 5\% Additive & $5 \%$ \\
\hline 5 & C & Untreated & $6.04 \%$ \\
\hline
\end{tabular}

* Volumetric strain under wetting load $12.5 \mathrm{kPa}$ for soils (A \&B), and $50 \mathrm{kPa}$ for soil (C) 
The mesh average element size and the number of the 10-node triangular elements depend on the global coarsenesses setting. The simple global finite element mesh of model is generated to present a more accurate stress distribution. The medium setting of mesh was selected by conducting patching test and multiple trials between other coarseness settings introduced in Plaxis-3D, were found to be most suitable, and provide a sufficient accuracy.

Calculation stages consist of 8 phases. In phase 1; the footing, interface and load are inactivated. Expansive soil model is fully saturated state condition, ground water levels and related saturation state conditions are simulated by Van-Genuchten hydraulic model. Phase 2; the footing, interface is activated. Phase 3; the footing, interface is activated with volumetric strain for untreated and treated soils, without change any other conditions. Phase 4 to Phase 8; the footing, interface and loading (12.5 kPa for soil (A \& B), $50 \mathrm{kPa}$ for soil (C) are activated with non-volumetric strain, and other conditions are kept constant.

\subsection{Numerical Model Results}

The deformations of untreated and treated expansive soils have been measured under different stress levels. The deformation pattern is illustrated in Figures (5) to (7).

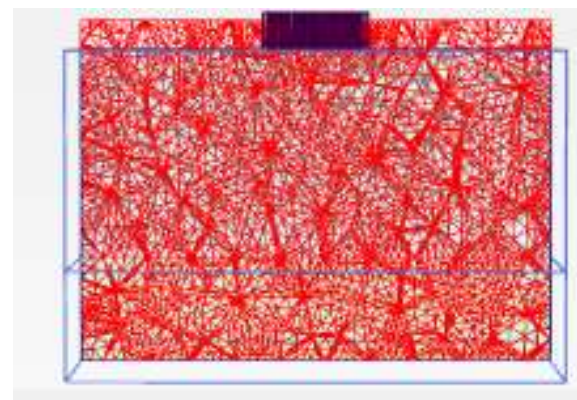

5-(a)

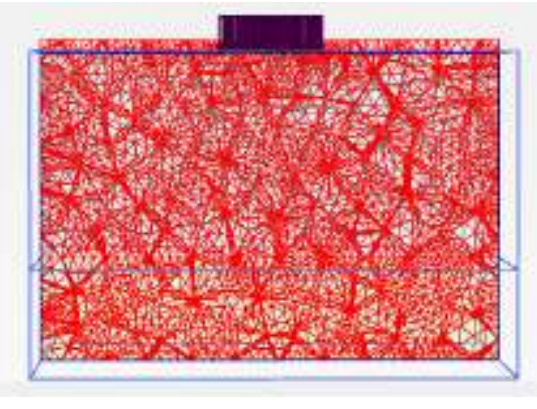

5-(b)

Figure 5. Deformed mesh under stress $12.5 \mathrm{kPa}$ for Soil (A), a. untreated b. treated

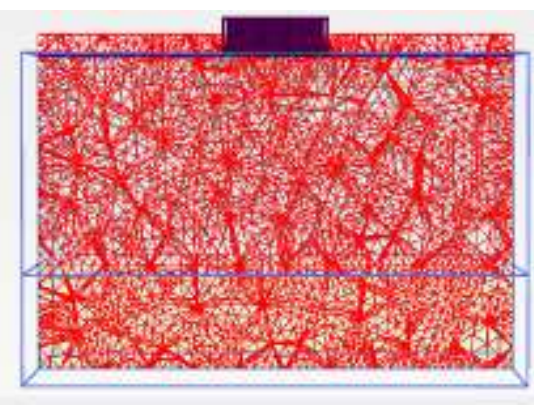

6-(a)

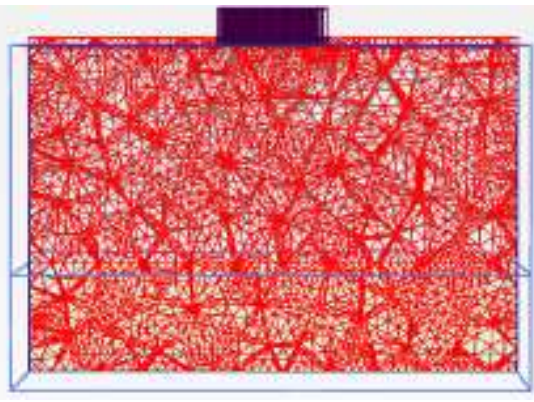

6-(b)

Figure 6. Deformed mesh under stress $12.5 \mathrm{kPa}$ for Soil (B), a. untreated b. treated.

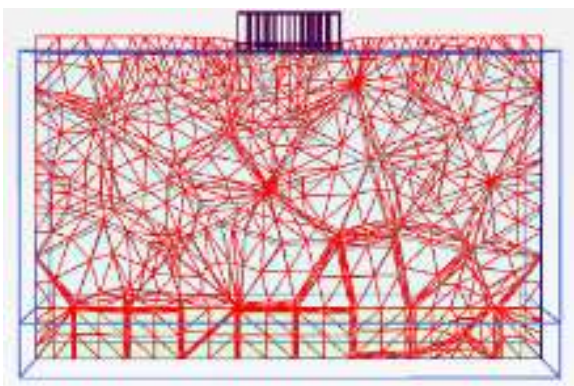

Figure (7) Deformed mesh for Soil (C) under stress $50 \mathrm{kPa}$ 


\section{Parametric Study}

\subsection{Volumetric Strain Value}

Soils A and B are modeled by HSM in Plaxis-3D with different of volumetric strain which listed in Table (6).

Table (6) Volumetric strain values for FEM

\begin{tabular}{|c|c|c|c|}
\hline Testing & Additive & $\left(+\varepsilon_{\mathbf{v}}\right)$ Soil A & $\left(+\varepsilon_{\mathbf{v}}\right)$ Soil B \\
\hline 1 & Untreated & $14 \%$ & $10 \%$ \\
\hline 2 & 1\% Silica fume & $12.57 \%$ & $10.8 \%$ \\
\hline 3 & 3\% Silica fume & $8.8 \%$ & $5.77 \%$ \\
\hline 4 & $5 \%$ Silica fume & $6.5 \%$ & $4 \%$ \\
\hline 5 & $7 \%$ Silica fume & $16.8 \%$ & $12 \%$ \\
\hline 6 & 1\% Slag & $14.82 \%$ & $10.8 \%$ \\
\hline 7 & 3\% Slag & $11.32 \%$ & $6.3 \%$ \\
\hline 8 & 5\% Slag & $6.5 \%$ & $5 \%$ \\
\hline 9 & $7 \%$ Slag & $15.5 \%$ & $12 \%$ \\
\hline
\end{tabular}

In previous case, these soils are treated by 1, 3,5 and 7\% Silica fume and Slag. These soils tested by oedometer tests. Volumetric strain values are approximately equal 0.25 the oedometer swelling potential. For soil $\mathrm{C}$, the volumetric strain is $6.04 \%, 4.308 \%, 3.468 \%$, and $3.10 \%$ (Abdelrahman et al., 2021).

For soils $\mathrm{A}$ and $\mathrm{B}$ are verified by Plaxis-3D under loading $12.5 \mathrm{kPa}$. In previous case, the loading increase to $25,50,100$ and $150 \mathrm{kPa}$. But for soil $\mathrm{C}$ was verified under $50 \mathrm{kPa}$. So, the loading increase to 100 and $150 \mathrm{kPa}$. The aim of increase the loading is to bring the heave of soil to the original height of its. The stress required to bring the specimen to the original height is interpreted as the 'Swelling Pressure'. Figures (8) to (10) show that, Numerical estimated swelling pressure for soils.

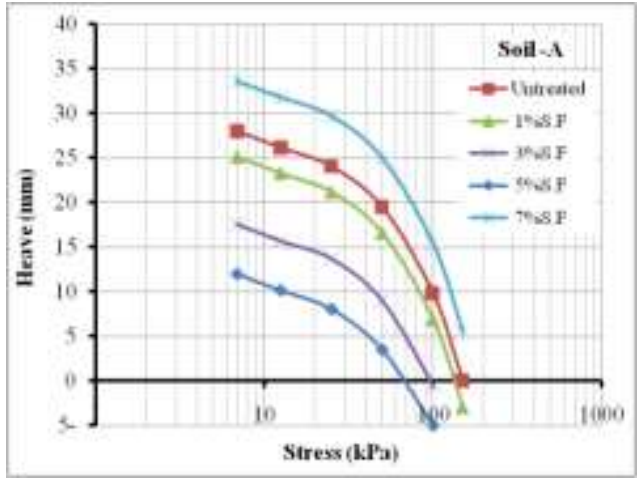

8-(a) Silica fume

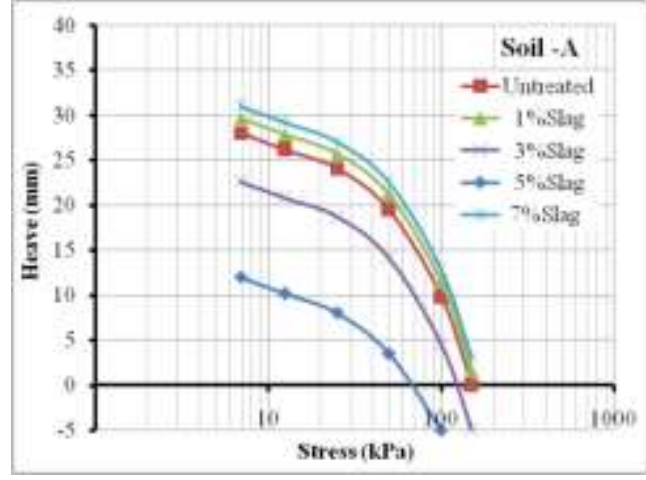

8-(b) Slag

Figure (8) Numerical Estimated Swelling Pressure for soil (A) treated by, a. Silica fume and b. Slag 


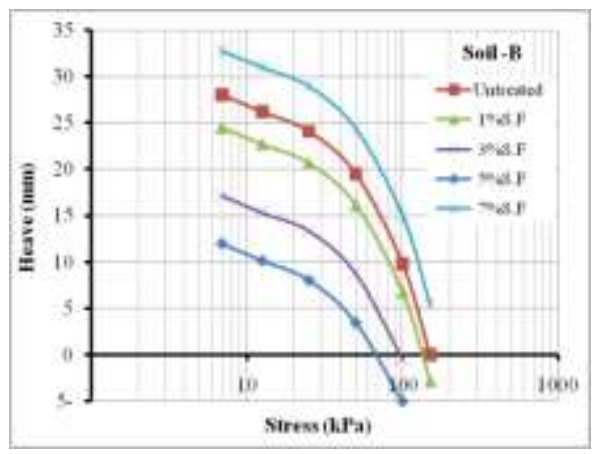

9-(a) Silica fume

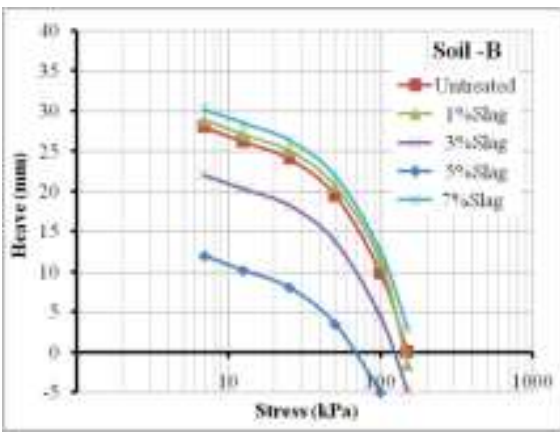

9-(b) Slag

Figure (9) Numerical Estimated Swelling Pressure for soil (B) treated by, a. Silica fume and b. Slag

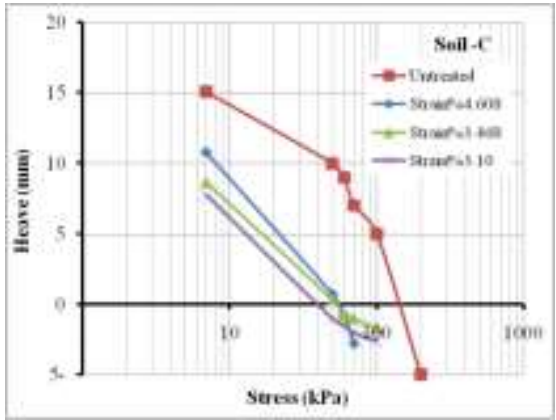

Figure (10) Numerical Estimated Swelling Pressure for soil (B)

\section{Comparison between Laboratory and Numerical Results}

The time-swelling potential relationship measured from laboratory model has been compared with those estimated from the oedometer tests. Numerical model is simulated the results of laboratory models. Figures (11) to (13) show the relationship between swelling potential and time for tested soil under stress $12.5 \mathrm{kPa}$ for soils (A \& B), $50 \mathrm{kPa}$ for soil (C). It can be observed that the oedometer exhibited higher rate of swelling potential during the first day, the laboratory and numerical models yielded nearly the same trend after about 45 days. The results as summarized in Table (7) indicate that, untreated soil in laboratory model swelled up to $14 \%$ after 45 days, while according to Figure (11), the addition of 5\% Silica fume or Slag to samples reduced swelling potential by about to $60 \%$. The swelling potential (S.P) estimated from the oedometer test is about four times that observed from laboratory

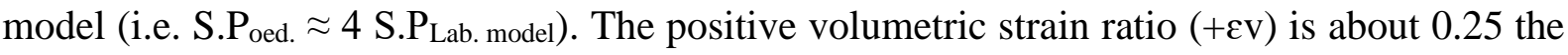
swelling potential value that estimated from the oedometer tests (i.e. $+\varepsilon v \approx 0.25 \mathrm{SP}_{\text {oed. }}$ ). The heave, Swelling Potential (S.P) and swelling pressure (Ps) estimated from the oedometer and laboratory model tests are compared with the numerical results in Table (7). The results show that, the swelling potential estimated from the oedometer test is about four times that observed from laboratory or numerical models. The heave decreased in case treated soils, the swelling pressure increase due to the positive pozzolanic reaction between soil and additives. This could be due to the bond between soil and additives which caused cementations reactions of Silica fume and Slag in specimen. On the other hand, curing time is very important factor to active this reaction. The swelling pressure estimated from the oedometer test for untreated and treated soils is about four and six-eight times that observed from numerical models, (i.e. $\mathrm{PS}_{\text {oed. }} \approx 4 \mathrm{PS}_{\mathrm{S}_{\text {Numerical }}}$ for untreated soil and $\mathrm{Ps}_{\text {Numerical }} \approx 6-8 \mathrm{Ps}_{\text {oed. }}$ for treated soil). Due to the very fine particles of additives, pozzolanic reactions between soil and additives are done 
quickly generating and cause cementations materials when absorbing moisture. As a result of these reactions, soil structure is changed to a cementations structure which reduces soil volume changes.

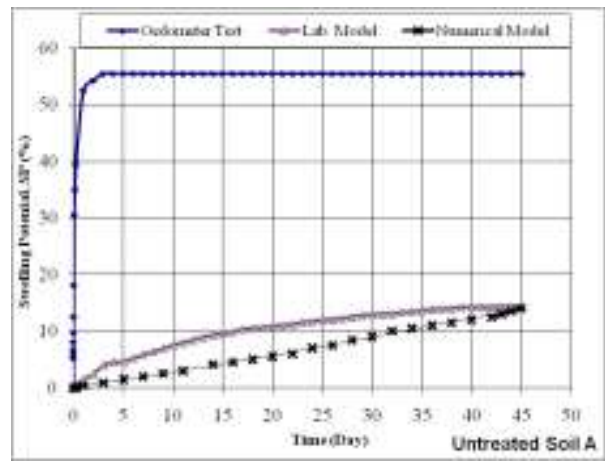

11-(a) Soil (A), untreated

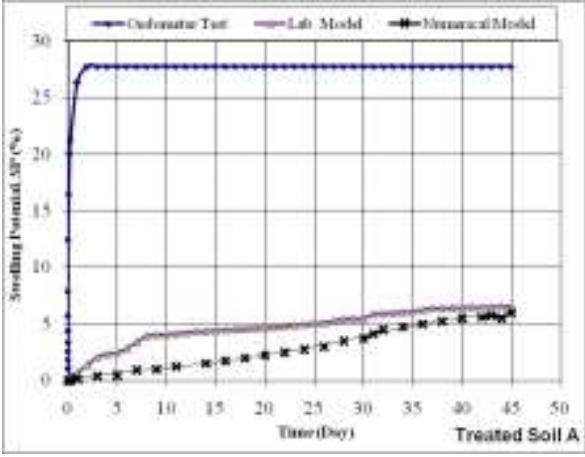

11-(b) Soil (A), treated

Figure (11) Swelling Potential - Time Curves for soil A, a. untreated and b. treated.

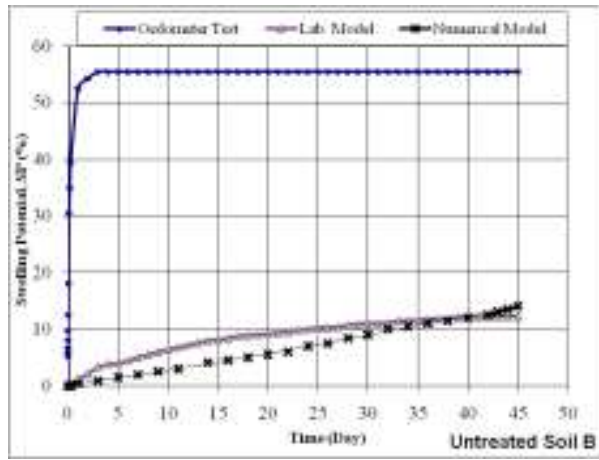

12-(a) Soil (B), untreated

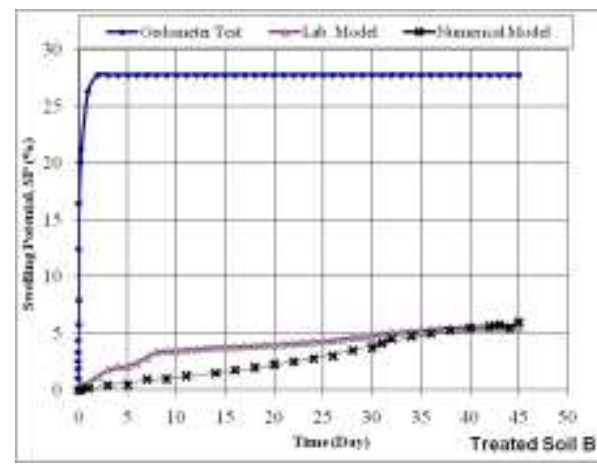

12-(b) Soil (B), treated

Figure (12) Swelling Potential - Time Curves for soil B, a. untreated and b. treated.

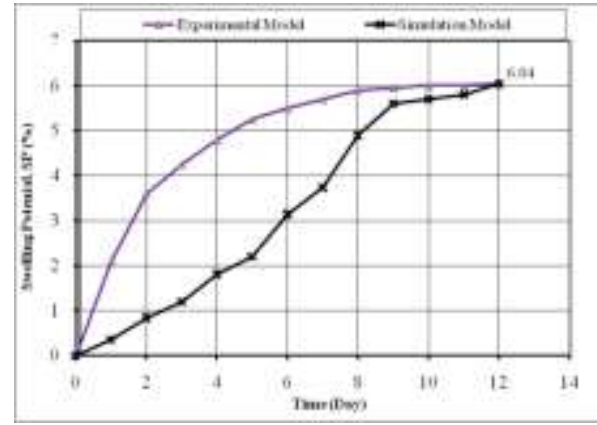

Figure (13) Swelling Potential - Time Curves for soil C.

Table (7) Swelling Characteristics of the different Tested Specimens

\begin{tabular}{|c|c|c|c|c|c|c|c|c|c|c|c|}
\hline \multirow[b]{2}{*}{ Test* } & \multicolumn{4}{|c|}{ Oedometer test } & \multicolumn{3}{|c|}{ Lab. models } & \multicolumn{4}{|c|}{ Numerical models } \\
\hline & $\begin{array}{l}\text { Height } \\
(\mathrm{mm})\end{array}$ & $\begin{array}{c}\text { Heave } \\
(\mathrm{mm})\end{array}$ & $\begin{array}{l}\text { S.P } \\
(\%)\end{array}$ & $\begin{array}{c}\text { Ps } \\
(\mathrm{kPa})\end{array}$ & $\begin{array}{l}\text { Height } \\
(\mathrm{mm})\end{array}$ & $\begin{array}{c}\text { Heave } \\
(\mathrm{mm})\end{array}$ & $\begin{array}{l}\text { S.P } \\
(\%)\end{array}$ & $\begin{array}{c}\text { Height } \\
(\mathrm{mm})\end{array}$ & $\begin{array}{c}\text { Heave } \\
(\mathrm{mm})\end{array}$ & $\begin{array}{l}\text { S.P } \\
(\%)\end{array}$ & $\begin{array}{c}\text { Ps } \\
(\mathrm{kPa})\end{array}$ \\
\hline Soil A & 16.7 & 9.27 & 55 & 600 & \multirow{3}{*}{200} & 29 & 14.5 & \multirow{3}{*}{200} & 28.83 & 14.4 & 150 \\
\hline Soil A $+5 \%$ Silica fume & 16.7 & 4.78 & 28 & 1000 & & 13 & 6.5 & & 13.16 & 6.5 & 70 \\
\hline Soil A $+5 \%$ Slag & 15.3 & 5.19 & 34 & 1200 & & 12 & 6 & & 13.16 & 6.5 & 70 \\
\hline Soil B & 16.7 & 6.82 & 40 & 400 & \multirow{3}{*}{200} & 21.39 & 10.6 & \multirow{3}{*}{200} & 20 & 10 & 110 \\
\hline Soil B $+5 \%$ Silica fume & 16.7 & 3.50 & 21 & 800 & & 12.83 & 6.4 & & 8 & 4 & 50 \\
\hline Soil B $+5 \%$ Slag & 15.3 & 3.48 & 23 & 800 & & 12.04 & 6 & & 8 & 4 & 50 \\
\hline
\end{tabular}

* All tested under stress $12.5 \mathrm{kPa}$ and values are recorded through 45 days. 


\section{Conclusions}

1.Utilization of pozzolanic by-products decreases the potential swelling of expansive soils. The optimum percentage of used pozzolanic Silica fume or Slag is found to be at range 3$5 \%$.

2.From oedometer tests, the swelling potential measured by oedometer tests decreased by about $40 \%$, while swelling pressure by Preswelled method increased by about $40 \%$ with treated soil by $5 \%$ of Silica fume or Slag.

3.From laboratory model results, the swelling potential decreased by about $60 \%$ for soil treated with $5 \%$ of Silica fume or Slag under stress $12.5 \mathrm{kPa}$.

4.Hardening Soil Model with volumetric strain ratio is considered a simple and suitable model for practicing the volume change of expansive soils.

5.Volumetric strain ratio is equal 0.25 of swelling potential value from oedometer test.

6. The swelling potential estimated from the oedometer test is about 4 times that observed from laboratory model.

7.Swelling pressure estimated from the oedometer test for untreated and treated soils is about 4 and 6-8 times that observed from numerical models, respectively.

\section{References}

[1] Abdelrahman, G. E., Youssef, Y. G., \& Abdeltawab, A. E. (2021). Effect of Sand Cushion Thickness and Lateral Extension on Heave of Remolded Swelling Soil. Hany Farouk Shehata, SSIGE, Soil-Interaction Group in Egypt SSIGE, Cairo Egypt. https://doi.org/10.1007/978-3030-62908-3_12

[2] Agus, S. S., Schanz, T., \& Fredlund, D. G. (2010). Measurements of suction versus water content for bentonite-sand mixtures. In Canadian Geotechnical Journal (p. 120). https://doi.org/10.1139/T09-120

[3] Al-Busoda, B. S., \& Abbas, H. O. (2017). Numerical Simulation of Mitigation of Soil Swelling Problem under Communication Tower Using Helical Piles. Journal of Geotechnical Engineering (JoGE), 4(3).

[4] Al-Busoda, B. S., Awn, S. H. A., \& Abbase, H. O. (2017). Numerical modeling of retaining wall resting on expansive soil. Geotechnical Engineering, 48(4).

[5] ASTM D4546. (2014). American Society of Testing Materials D 4546. In American Association of State Highway and Transportation Officials. https://doi.org/10.1520/D4546-08.2

[6] Katti, R. K. (1979). SEARCH FOR SOLUTIONS TO PROBLEMS IN BLACK COTTON SOILS. In Indian Geotechnical Journal (pp. 1-58).

[7] Likitlersuang, S., Chheng, C., Surarak, C., \& Balasubramaniam, A. (2018). Strength and stiffness parameters of Bangkok clays for finite element analysis. Geotechnical Engineering, $49,150-156$.

[8] Sahoo, J. P., \& Pradhan, P. K. (2010). Effect of Lime Stabilized Soil Cushion on Strength Behaviour of Expansive Soil. Geotechnical and Geological Engineering, 28, 889-897. https://doi.org/10.1007/s10706-010-9332-6

[9] Sridharan, A., \& Gurtug, Y. (2004). Swelling behaviour of compacted fine-grained soils. Engineering Geology, 72(1-2), 9-18. https://doi.org/10.1016/S0013-7952(03)00161-3

[10] Sridharan, A., \& Prakash, K. (2000). Classification procedures for expansive soils. Proceedings of the Institution of Civil Engineers: Geotechnical Engineering, 143(4), 235-240. https://doi.org/10.1680/geng.2000.143.4.235

[11] Thakur, V., \& Singh, D. (2005). Rapid Determination of Swelling Pressure of Clay Minerals. Journal of Testing and Evaluation, 33(4), 11866. https://doi.org/10.1520/jte11866

[12] Vanapalli, \& Taylan. (2012). Design of Single Piles Using the Mechanics of Unsaturated Soils. Journal of GeoMate.

[13] Zaki, A. H., Gad, S., \& Alsedik, M. A. (2021). Behavior of Expansive Soil Treated by Pozzolanic Materials. Al-Azhar Engineering, 15th International Conf., 411-419. 